Pesq. Vet. Bras. 29(6):452-456, junho 2009

\title{
Phenotypical characterization of Candida spp. isolated from crop of parrots (Amazona spp.) $)^{1}$
}

\begin{abstract}
Renata G. Vieira ${ }^{2}$ and Selene D. Acqua Coutinho ${ }^{2^{*}}$
ABSTRACT.- Renata G. Vieira R.G. \& Acqua Coutinho S.D. 2009. Phenotypical characterization of Candida spp. isolated from crop of parrots (Amazona spp.). Pesquisa Veterinária Brasileira 29(6):452-456. Curso de Pós-Graduação em Imunopatologia Veterinária, Universidade Paulista, Rua Agariba 48, São Paulo, SP 05053010, Brazil. E-mail: selene@uol.com.br

The purpose of this study was to characterize Candida isolates from crop of parrots. Forty baby parrots of genus Amazona, species aestiva and amazonica that were apprehended from wild animal traffic were used: 18 presented ingluvitis and 22 other alterations, but showing general debilitation. Samples were seeded on Sabouraud dextrose agar with chloramphenicol after be obtained by the introduction of urethral probe through the esophagus. Based on morphology and biochemical reactions (API 20C) Candida was confirmed; it was still searched the production of proteinase and phospholipase, virulence factors for Candida species. Candida spp. were isolated from $57.5 \%$ parrots, being $72.2 \%$ from birds with ingluvitis and $45.5 \%$ from without ones. Twenty-five strains of Candida were isolated, $60 \%$ and $40 \%$, respectively from parrots with and without ingluvitis, and were speciated: $28 \%$ C. humicola, $24 \%$ C. parapsilosis, $20 \%$ C. guilliermondii, $20 \%$ C. famata, and $8 \%$ C. albicans. These results demonstrate that $C$. albicans is not the most frequent species isolated, and it is the first report that shows $C$. guilliermondii, $C$. famata, and $C$. humicola causing infection in parrots. Many isolates presented filamentation (76\%), $100 \%$ produced proteinase and $68 \%$ phospholipase. The observation of Candida spp. producing virulence factors reinforce the pathogenic role of these yeasts in the cases studied.
\end{abstract}

INDEX TERMS: Candida spp., candidiasis, crop, ingluvitis, parrots, Amazona spp.

RESUMO.- [Caracterização fenotípica de Candida spp. isoladas de inglúvio de papagaios (Amazona spp.).] $\mathrm{O}$ objetivo do presente trabalho foi caracterizar cepas de Candida spp. isoladas de inglúvio de papagaios. Foram utilizados 40 papagaios do gênero Amazona, espécies aestiva e amazonica, apreendidos de tráfico de animais selvagens: 18 apresentavam ingluvite e 22 outras alterações, mas todos mostrando sinais de debilitação geral. Colheram-se as amostras clínicas através da introdução de sonda uretral no esôfago dos animais e estas foram semeadas em ágar Sabouraud dextrose acrescido de cloranfenicol. A identificação das espécies de Candida foi

\footnotetext{
${ }^{1}$ Received on October 13, 2008.

Accepted for publication on March 11, 2009.

${ }^{2}$ Curso de Pós-Graduação em Imunopatologia Veterinária da Universidade Paulista (Unip), Rua Agariba 48, São Paulo, SP 05053-010, Brazil. * Corresponding author: selene@uol.com.br
}

baseada em características macro e micromorfológicas e comportamento bioquímico no kit API 20C; pesquisou-se ainda a produção das enzimas proteinase e fosfolipase. Isolou-se Candida spp. de $57,5 \%$ dos papagaios, sendo $72,2 \%$ de aves com ingluvite e $45,5 \%$ de aves com outras afecções. Isolaram-se 25 cepas de Candida, 60\% e 40\% respectivamente de animais com e sem ingluvite. As espécies isoladas foram: C. humicola (28\%), C. parapsilosis (24\%), C. guilliermondii (20\%), C. famata $(20 \%)$ e C. albicans (8\%). Os resultados obtidos demonstram que $C$. albicans não é a espécie mais freqüentemente isolada e é a primeira vez que se relata $C$. guilliermondii, $C$. famata e $C$. humicola causando infecção em papagaios. A maioria dos isolados apresentou filamentação (76\%) e produziu a enzima fosfolipase (68\%) e todas as cepas produziram proteinase. $\mathrm{O}$ encontro de Candida spp., produzindo seus fatores de virulência, reforça o papel patogênico dessas leveduras nos casos estudados. 
TERMOS DE INDEXAÇÃO: Candida spp., candidíase, inglúvio, ingluvite, papagaios, Amazona spp.

\section{INTRODUCTION}

Candida albicans is yeast that can be present in the digestive, urinary and reproductive tracts of birds, and it is common to isolate few of these fungi from healthy animals (Mancianti et al. 2002). It may, however, be the cause of gastroenteropathies (Harrison 1986, Speer 1995, Kano et al. 2001, Schmidt et al. 2003). Candidiasis may occur as a primary or secondary infection, such as due to prolonged use of antibiotics, vitamin A deficiency, avian pox, trichomoniasis, chronic stress, malnutrition, and unsanitary conditions (Harrison 1986, Speer 1995, Schmidt et al. 2003, Godoy 2006).

Clinical signs of candidiasis depend on the site of infection, and the crop is the most commonly affected organ in young birds (Speer 1995, Lamberski 2003). Signs of crop infection include regurgitation, delay in crop emptying and crop dilatation, depression, anorexia and weight loss, emaciation, and growth impairment (Speer 1995, Lamberski 2003, Schmidt et al. 2003, Godoy 2006).

Host-parasite relationships depend on the balance between the virulence of the microorganism and defenses of the host. As for Candida sp., it is known that some deficiencies in the immune response are usually present for disease occurrence. However, some Candida strains are so virulent that they can cause infections in apparently healthy individuals. The ability to produce filaments, to adhere to epithelial surfaces and to secrete hydrolytic enzymes seems to be the most important virulence factor for Candida (Barret-Bee et al. 1985, Odds 1985, Dolan et al. 2004). In these situations, the incidence of candidiasis may increase, and the yeast presents characteristics of an actual opportunistic microorganism (Barret-Bee et al. 1985).

The occurrence of candidiasis is suspected when blastoconidia associated with pseudohyphae or true hyphae are found, once filamentation represents in vivo increase of pathogenicity (Barret-Bee et al. 1985, Koneman \& Roberts 1990).

Many microorganisms produce hydrolytic enzymes that favor their pathogenicity. It has already been demonstrated that the secretion of enzymes is an important virulence factor for $C$. albicans, making easier its penetration into tissues (Price et al. 1982, Rüchel et al. 1982, Barret-Bee et al. 1985, Odds 1985, Dolan et al. 2004).

In humans, the ever growing number of fungal infections, mainly candidiasis, is strongly associated with concurrent immunosupressing diseases, such as tumors and AIDS (Bodey et al. 2002, Costa et al. 2006). In poultry, this association has been observed by researchers with the description of candidiasis associated with coccidiosis in turkeys (Moretti et al. 2000). Candida spp. were also isolated from the lungs of pigeons that presented concomitant cryptococcosis (Bernardo et al. 1994) and from psittacines kept in captivity (Hinz et al. 2000) which is also a stressful/debilitating condition for the animals (Lamberski 2003).

Studies have shown that the illegal trade and the loss of habitats are the main risk factors for the 90 endangered psittacine species in the world (IUCN 2008). From a total of 344 species known, 72 are found in Brazil, and $40 \%$ of them are rare and/or endangered (IUCN 2008). Therefore, studies that enable a better understanding of the diseases that affect these animals contribute for the management and survival of these species.

The objective of this study was to characterize phenotypically strains of Candida isolated from the crop of parrots of the genus Amazona, in order to better understand the role that these yeasts may play in the overall health of these birds.

\section{MATERIALS AND METHODS}

\section{Selection of the population}

Forty baby parrots of genus Amazona, species aestiva (Blue-fronted parrot, 29 animals) and amazonica (Orangewinged parrot, 11 animals), were used in this study. They were apprehended by forest police from illegal trade (Fig.1) and placed into a governmental recovery center. Eighteen birds presented clinical signs compatible with ingluvitis - delay in emptying the crop, regurgitation, depression, anorexia, emaciation, and diarrhea (Kano et al. 2001, Lamberski 2003, Schmidt et al. 2003). Although 22 of them did not present any signs of ingluvitis, they were so debilitated; some of them presented bone dislocations and/or fractures, chronic wounds and dyspnea due to transportation stress and overpopulation.

\section{Specimen collection}

Samples were obtained from the crop using a sterile urethral probe $\mathrm{n}^{\circ} 8$ or 10 through the esophagus of the birds. Samples were transferred to sterile swabs, which were kept under refrigeration and sent to the laboratory within up to $24 \mathrm{~h}$.

\section{Direct examination}

Direct examination of the clinical samples was performed by means of a smear of the crop secretion on a slide, which

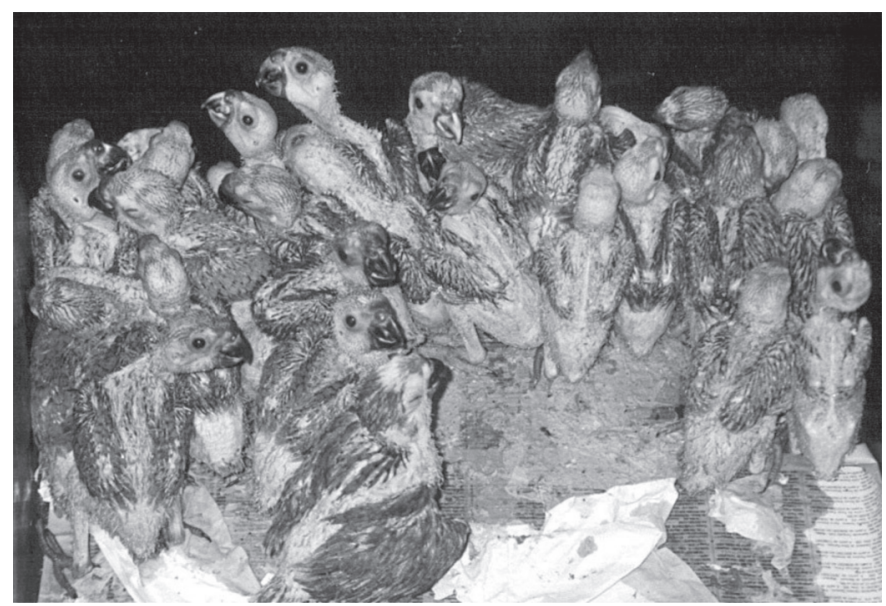

Fig.1. Babe parrots (Amazona aestiva) recently arrived in the recovery center, apprehended from illegal trade of wild animals. 
was Gram-stained. Morphology and number of buds, and presence or absence of filamentation (germ tube, pseudohyphae and/or true hyphae) were searched (Koneman \& Roberts 1990).

\section{Isolation}

Samples were cultured onto Petri dishes containing Sabouraud dextrose agar (Difco ${ }^{\mathrm{TM}}$ ) with chloramphenicol $(100 \mathrm{mg} / \mathrm{L})$. Incubation was performed at $37^{\circ} \mathrm{C}$ for seven days.

\section{Morphologic characterization}

Production of germ tube. This technique was performed by means of suspension of the strain in a tube containing $0.5 \mathrm{~mL}$ of sterile rabbit serum, followed by incubation at $37^{\circ} \mathrm{C}$. After that, the suspension was placed on a glass slide covered with a cover slip, and examined every hour, for 4 hours, under a light microscope, in order to assess the production of germ tube (Koneman \& Roberts 1990).

Filamentation. This test was performed on a sterile glass slide covered with rice agar ${ }^{3}$ (Koneman \& Roberts 1990). After solidification, one sample of the colony was streaked in parallel and equidistant lines on the surface of the agar, which was partially covered with a sterile cover slip. Incubation was performed in a humid chamber at $37^{\circ} \mathrm{C}$ for $24-48 \mathrm{~h}$. Growth was observed under optical microscope, in order to assess the production of blastoconidia, chlamydoconidia, pseudohyphae, and true hyphae (Koneman \& Roberts 1990).

\section{Biochemical identification}

Biochemical characterization to confirm genus and species was performed using kit API 20C AUX Bio-Mérieux (API ${ }^{\circledR}$, Analitical Profile Index, BioMérieux SA, France).

\section{Exoenzymes production}

Proteinase and phospholipase. The production of proteinase and phospholipase was investigated by employing the techniques described for C. albicans (Price et al. 1982, Rüchel et al. 1982). For the production of proteinase (Prz) the readings were taken after 24,48 , and $72 \mathrm{~h}$. For the production of phospholipase $(\mathrm{Pz})$ the readings were done after $48,72,96 \mathrm{~h}$ and after 5 , and 7 days. The formation of a halo (zone of precipitation) around the colony was considered to indicate enzyme production. The enzymatic activities (Prz and Pz i.e., activities of enzymes proteinase and phospholipase as noted above) were measured in terms of the ratio of colony diameter to the total diameter of colony plus the zone of precipitation (Price et al. 1982). Therefore, $\mathrm{Pz}=1.00$ would be a negative strain; $\mathrm{Pz}$ $<1.00$ and $\geq 0.64$ would be a positive strain and $\mathrm{Pz}<0.64$ would be a strongly positive strain for the production of the enzymes (Price et al. 1982).

\section{Statistical analysis}

Variance analysis tests were applied to compare Candida isolates in birds with and without ingluvitis; the rejection level of the null hypothesis was fixed at 0.05 or $5 \%(p \leq 0.05)$ (Zar 1996).

${ }^{3}$ Rice $(20 \mathrm{~g})+$ water $(1 \mathrm{~L})$, to boil during 45 minutes; to pass the solution through a filter and to add bacteriological agar $(2 \%)$; to place in an autoclave at $120^{\circ} \mathrm{C}$ for 15 minutes.

\section{RESULTS}

\section{Selection of the population}

Candida spp. were isolated from $23 / 40$ (57.5\%) parrots, being $13 / 18(72.2 \%)$ from birds with clinical signs of ingluvitis and 10/22 (45.5\%) from without ingluvitis; there was no significant differences in behavior between the isolates originating in infection of the crop or not. Twentyfive strains of the Candida spp. were isolated, 15/25 (60\%) and 10/25 (40\%), respectively from animals with and without ingluvitis, with no statistical differences between them. Therefore, in the other tests, a total of 25 strains of Candida were used.

\section{Morphologic characterization}

Direct examination. The presence of round, oval and/ or elongated yeast cells, with single or multiple buds was observed. In 11 out of 25 strains (44\%), direct examination showed the presence of germ tube, pseudohyphae and/or true hyphae (Fig.2).

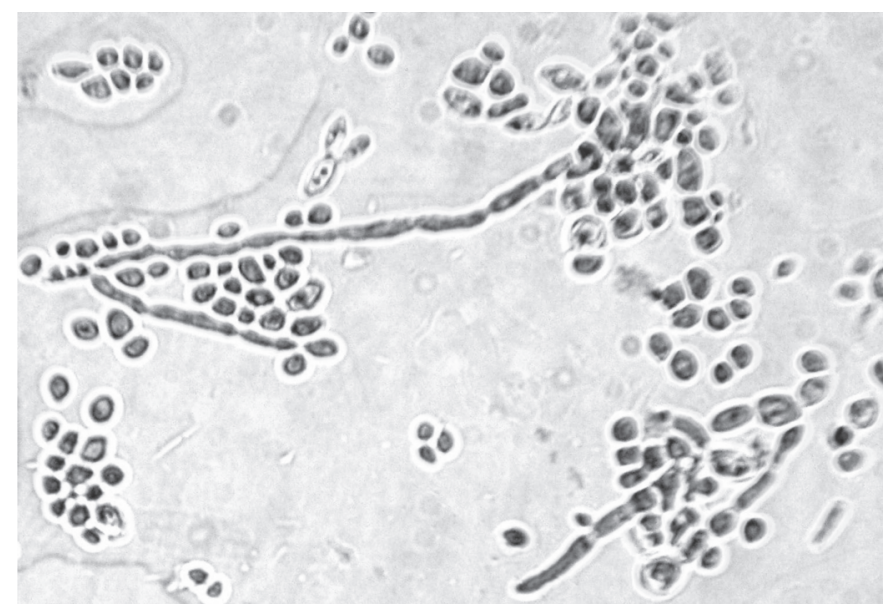

Fig.2. Candida humicola presenting filamentation in direct examination of crop specimen. Gram-stained, magnification $1,000 x$.

Production of germ tube and filamentation. It was observed that 19 out of 25 strains (76\%) produced germ tube, pseudohyphae and/or true hyphae (Table 1), and 2 out of $25(8 \%)$ produced chlamydoconidia (C. albicans).

\section{Biochemical characterization}

Five species of genus Candida were identified, being $28 \%(7 / 25)$ C. humicola, 24\% (6/25) C. parapsilosis, $20 \%$ (5/25) C. guilliermondii, 20\% (5/25) C. famata, and $8 \%(2 /$ 25) C. albicans. The occurrence of mixed infection, caused by two different species, was observed in two animals (Table 1).

\section{Exoenzymes production}

Proteinase and phospholipase. All strains strongly produced proteinase enzyme, after $72 \mathrm{~h}$, having mean value $\operatorname{Prz}=0.28$ (Table 1). Concerning phospholipase production, $17 / 25$ (68\%) strains produced that enzyme, 
Table 1. Phenotypical characterization of Candida strains isolated from crop of parrots (Amazona aestiva and A. amazonica)

\begin{tabular}{|c|c|c|c|c|c|c|}
\hline Strain & Species & Ingluvitis & Filamentation & Candida spp. & Proteinase ${ }^{a}$ & Phospholipase ${ }^{b}$ \\
\hline $1 a$ & A. aestiva & Presence & Positive & C. parapsilosis & 0.24 & 0.81 \\
\hline $1 b$ & & & Positive & C. guilliermondii & 0.28 & 0.58 \\
\hline 2 & A. aestiva & Presence & Positive & C. albicans & 0.26 & 1 \\
\hline 3 & A. aestiva & Presence & Positive & C. parapsilosis & 0.22 & 1 \\
\hline 4 & A. aestiva & Presence & Positive & C. guilliermondii & 0.22 & 0.50 \\
\hline 5 & A. amazonica & Presence & Negative & C. famata & 0.27 & 0.79 \\
\hline 6 & A. amazonica & Presence & Positive & C. humicola & 0.21 & 1 \\
\hline $7 a$ & A. aestiva & Presence & Positive & C. humicola & 0.20 & 1 \\
\hline $7 \mathrm{~b}$ & & & Positive & C. guilliermondii & 0.24 & 0.61 \\
\hline 8 & A. aestiva & Presence & Positive & C. humicola & 0.18 & 0.43 \\
\hline 9 & A. aestiva & Presence & Negative & C. famata & 0.45 & 0.60 \\
\hline 10 & A. aestiva & Presence & Positive & C. parapsilosis & 0.31 & 0.50 \\
\hline 11 & A. aestiva & Presence & Negative & C. parapsilosis & 0.22 & 1 \\
\hline 12 & A. aestiva & Presence & Positive & C. parapsilosis & 0.22 & 0.86 \\
\hline 13 & A. amazonica & Presence & Positive & C. humicola & 0.31 & 0.42 \\
\hline 14 & A. aestiva & Absence & Positive & C. parapsilosis & 0.31 & 0.57 \\
\hline 15 & A. aestiva & Absence & Negative & C. famata & 0.18 & 0.76 \\
\hline 16 & A. amazonica & Absence & Positive & C. guilliermondii & 0.27 & 0.79 \\
\hline 17 & A. aestiva & Absence & Positive & C. humicola & 0.25 & 0.71 \\
\hline 18 & A. aestiva & Absence & Negative & C. famata & 0.36 & 1 \\
\hline 19 & A. aestiva & Absence & Negative & C. famata & 0.36 & 1 \\
\hline 20 & A. amazonica & Absence & Positive & C. humicola & 0.27 & 0.47 \\
\hline 21 & A. amazonica & Absence & Positive & C. albicans & 0.36 & 0.54 \\
\hline 22 & A. aestiva & Absence & Positive & C. guilliermondii & 0.45 & 0.75 \\
\hline 23 & A. aestiva & Absence & Positive & C. humicola & 0.25 & 1 \\
\hline Mean & & & & & 0.28 & 0.75 \\
\hline
\end{tabular}

on readings taken on 7 days, having mean value $\mathrm{Pz}=$ 0.75 (Table 1).

\section{DISCUSSION}

The birds selected for the study came from illegal trade, and being submitted to the stress of capture, transportation, overpopulation and inadequate feeding, many times these birds had to be treated with antibiotics in the recovery center. These predisposing factors may have made these birds more susceptible to infections caused by opportunistic fungi, what supports the high isolation rate of Candida spp. from the crop of the animals in this study (23/40; $57.5 \%)$.

There were no differences in the isolation of Candida spp. among the birds with or without ingluvitis; besides, the behavior of the yeasts was not different in relation to filamentation and production of exoenzymes. It was concluded that, yeasts isolated were acting as opportunistic microorganisms, producing virulence factors in parrots with and without ingluvitis. Since Candida species are considered part of the microflora of the gastrointestinal tract, debilitated condition of the animal is essential for Candida to settle and multiply (Mancianti et al. 2002).

Candidiasis is frequent in human patients showing impaired immune response (Bodey et al. 2002, Costa et al. 2006), in animals the same situation is observed. $C$. rugosa was isolated from young turkeys with concomitant chronic coccidiosis, and postmortem findings showed excessive growth of the yeasts in the digestive tract of those birds, causing ulcerative lesions in the ventricle (Moretti et al. 2000). In samples of respiratory secretion from pigeons presenting cryptococcosis there were the concomitant isolation of Candida strains in about $15 \%$ of them (Bernardo et al. 1994).

Although, most veterinary texts consider $C$. albicans as the only species of the genus involved in the infections of the digestive tract of psittacines birds (Harrison 1986, Speer 1995, Schmidt et al. 2003), some researchers report species non-albicans of the genus Candida as responsible for infections in birds. C. parapsilosis has been reported as causing crop stasis, regurgitation, lethargy, weight loss, and diarrhea (Kano et al. 2001, Lamberski 2003); C. krusei and $C$. tropicalis have already been isolated from the digestive tract of psittacine birds, malnourished, incorrectly managed and with inhibited bacterial microbiota due to the prolonged use of systemic antibiotics (Schmidt et al. 2003). In none of these studies the pathogenicity and virulence factors of the isolates were studied.

Only two (8\%) of the strains isolated in this project were identified as $C$. albicans; five species of the genus Candida were isolated from the crop of the parrots, including $C$. guilliermondii, C. famata, and C. humicola, which have not yet been reported as causing psittacine infection. Data related to the species isolated in this research, together with the low prevalence of $C$. albicans, show the importance 
of the results obtained, for they do not comply with what was reported before, and corroborate the tendency to consider other species of the genus Candida as pathogenic for birds (Kano et al. 2001, Lamberski 2003). Since there are different susceptibility profiles among Candida species (Bodey et al. 2002, Pfaller et al. 2002, Costa et al. 2006), it is important to know which is the species involved in the infection to be successful in the treatment of the animals.

It should be emphasized that the different Candida species isolated from the parrots have already been reported in human infections (Pfaller et al. 2002, Costa et al. 2006), and that these birds could characterize as source of infection for other animals, and also for those people that manage them, such as caretakers, biologists, and veterinarians (Mancianti et al. 2002).

Almost half of the strains (44\%) presented filamentation in the direct examination of the clinical sample; once the ability to filament is an indication for the pathogenicity of the isolates, a simple direct examination of the clinical sample Gram-stained may aid to understand the role the yeast plays in the animal analyzed (microflora or pathogen) (Barret-Bee et al. 1985, Koneman \& Roberts 1990).

The basic constitution of the vertebrate's cellular membrane is a double layer of phospholipids interspersed with proteins. Exposure to proteinase and phospholipase produced by microorganisms induces pores on these membranes, dismantling all cellular functions and favoring tissue invasion. Therefore, the production of exoenzymes is considered an important virulence factor for microorganisms (Barret-Bee et al. 1985, Odds 1985, Dolan et al. 2004). All Candida strains isolated in this research produced proteinase and $68 \%$ of them produced phospholipase, reinforcing the pathogenic role of these yeasts in the cases studied.

Since parrots are part of the family that has the greatest number of endangered species (IUCN 2008), a better understanding of the diseases that affect them permit establishing prophylactic and curative measures that increase the survival rate of these birds.

Acknowledgments.- To Centro de Estudos e Manejo de Animais Silvestres do Estado de São Paulo and Criadouro Comercial e Científico Poços de Caldas for allowing the collection of the samples.

\section{REFERENCES}

Barret-Bee K., Hayes Y., Wilson R.B. \& Ryley J.F. 1985. A comparison of phospholipase activity, cellular adherence and pathogenicity of yeasts. J. Gen. Microbiol. 131:1217-1221.

Bernardo F.M.A., Rodeia S.C. \& Martins H.M. 1994. On the epidemiological and pathological significance of cryptococcosis in urban pigeons in Lisbon, Portugal. Revta Port. Ciênc. Vet. 89:132-138.
Bodey G.P., Mardani M., Hanna H.A., Boktour M., Abbas J., Girgawy E., Hachem H.Y., Kontoyiannis D.P. \& Raad I. 2002. The epidemiology of Candida glabrata and Candida albicans fungemia in immunocompromised patients with cancer. Am. J. Med. 112:380-385.

Costa C.R., Lemos J.A., Passos X.S., Araújo C.R., Cohen A.J. \& Silva M.R. 2006. Species distribution and antifungal susceptibility profile of oral candida isolates from HIV-infected patients in the antiretroviral therapy era. Mycopathologia 162:45-50.

Dolan J.W., Bell A.C., Hube B., Schaller M., Warner T. \& Balish E. 2004. Candida albicans PLD1 activity is required for full virulence. Med. Mycol. 42:439-447.

Godoy S.N. 2007. Psittaciformes, p.222-251. In: Cubas Z.S., Silva J.C.R. \& Catão-Dias J.L. (Eds), Tratado de Animais Selvagens: Medicina veterinária. Roca, São Paulo.

Harrison G.J. 1986. Clinical Avian Medicine and Surgery. W.B.Saunders, Philadelphia. 717p.

Hinz K.H., Kummerfeld N., Ryll M. \& Braune S. 2000. Spectrum of bacterial and fungal pathogens in chronic lesions of the upper respiratory tract of psittacine birds. Kleintierpraxis 45:183-200.

IUCN 2008. Red List of Threatened Species. The World Conservation Union. Available in http://www.iucnredlist.org/. Access July 4, 2008.

Kano R., Sakamoto Y., Hanahachi A., Kamata H., Fukuda Y., Fujiwara K. \& Hasegawa A. 2001. Molecular identification of Candida parapsilosis from crop mucosa in a cockatiel. J. Vet. Diagn. Invest. 13:437-439.

Koneman E.W. \& Roberts G.D. 1990. Micologia: Practica de Laboratório. $3^{\underline{a}}$ ed. Editorial Medica Panamericana, Buenos Aires. 221p.

Lamberski N. 2003. Psittaciformes, p.207-208. In: Fowler M.E. \& Miller R.E. (Eds), Zoo and Wild Animal Medicine. $5^{\text {th }}$ ed. W.B. Saunders, Philadelphia.

Mancianti F., Nardoni S. \& Ceccherelli R. 2002. Occurrence of yeasts in psittacines droppings from captive birds in Italy. Mycopathologia 153:121-124.

Moretti A., Fioretti D.P., Boncio L., Pasquali P. \& Rossi E. 2000. Isolation of Candida rugosa from turkeys. J. Vet. Med. 47:433-439.

Odds F.C. 1985. Candida albicans proteinase as a virulence factor in the pathogenesis of Candida infections. Zentralbl. Bakteriol. Mikrobiol. Hyg. 1:539-542.

Pfaller M.A., Messer S.A., Hollis R.J., Jones R.N. \& Diekema D.J. 2002. In vitro activities of ravuconazole and voriconazole compared with those of four approved systemic antifungal agents against 6,970 clinical isolates of Candida spp. Antimicrob. Agents Chemother. 46:1723-1727.

Price M.F., Wilkinson I.D. \& Gentry L.O. 1982. Plate method for detection of phospholipase activity in Candida albicans. Sabouraudia 20:7-14.

Rüchel R., Tegeler R. \& Trost M.A. 1982. A comparison of secretory proteinases from different strains of Candida albicans. Sabouraudia 20:233-244.

Schmidt R.E., Reavill D.R. \& Phalen D.N. 2003. Pathology of Pet and Aviary Birds. lowa State Univ. Press, Ames. 234p.

Speer B.L. 1995. Infectious diseases, p.310. In: Abramson J., Speer B.L. \& Thomsen J.B. (Eds), The Large Macaws: Their care, breeding and conservation. Raintree Publications, Fort Bragg.

Zar J.H. 1996. Bioestatistical Analysis. $3^{\text {rd }}$ ed. Prentice Hall, New Jersey. $662 p$. 